\title{
FINANCIAL ANALYSIS ON THE EXAMPLE OF THE BUDESHTNOST TRADE COMPANY
}

\section{ANALIZA FINANSOWA NA PRZYKŁADZIE FIRMY HANDLOWEJ BUDESHTNOST}

\author{
Daniela Simeonova ${ }^{1}$ \\ VASIL LEVSKI NATIONAL MILITARY UNIVERSITY, \\ VELIKO TARNOVOA
}

\begin{abstract}
The modern market economy is characterized by an extraordinary dynamic of economic conditions, phenomena and processes. In such an environment, the development of a successful business requires both flexibility and rapid adaptation to the continuous changes, as well as a maximum objective and accurate idea of the actual state of the developed business activity and the prospects for its future development.

Streszczenie. Nowoczesna gospodarka rynkowa charakteryzuje się niezwykłą dynamiką warunków, zjawisk i procesów gospodarczych. W takim otoczeniu rozwój udanego biznesu wymaga zarówno elastyczności i szybkiego dostosowywania się do ciągłych zmian, jak i maksymalnego celu i dokładnego wyobrażenia o rzeczywistym stanie rozwiniętej działalności gospodarczej i perspektywach jej przyszłego rozwoju.
\end{abstract}

Keywords: economy, financial analysis, trade company.

Słowa kluczowe: gospodarka, analiza finansowa, przedsiębiorstwo handlowe.

\section{Introduction}

It is the financial analysis that allows establishing and quantifying the dependence between the final result of the business activity and the means, factors and

1 Sergeant major Daniela Simeonova - Vasil Levski National Military University, Veliko Tarnovo, specialty: material resources, movement and transport; e-mail: progressive__@abv.bg.

Starszy sierżant Daniela Simeonova - Militarny Uniwersytet im. Wesyla Levskiego, Veliko Tarnowo, specjalność: zasoby materiałowe, ruch i transport wojsk; e-mail: progressive__@abv.bg. 
prerequisites that form its development. The business analysis gives us information about the current state of the company and how and why it has reached this state. But it also allows us to predict the possible future development of an enterprise and, more importantly, to determine what and how it should change in order for the company to move in the desired direction.

\section{Theoretical basis of the financial analysis}

Financial analysis is a tool for comprehensive, complete and complete understanding of all aspects of the business activity of the company. It is a system of comprehensive and interconnected study of the financial, business and commercial activities of companies as systems. On the basis of the financial analysis, options are developed to increase the efficiency of the use of production and financial resources in the conditions of dynamically changing and production situations and market conjuncture. It is done by examining different indicators of the financial situation of the enterprise concerned, the main purpose being not so much to determine the magnitude of these indicators but to determine and study the factors that determine them. On this basis the opportunities for the future development of the company are studied, advice and recommendations are given. The company's financial analysis should be developed on the principles of complexity, system, continuity, operability, justification, etc.

Analysis, as well as forecasting, planning, reporting, control and regulation, must be carried out on an ongoing basis.

The main tasks facing the financial analysis are:

1. Evaluation of the achieved results in the conduct of the business activity of the company.

2. Discovering and studying the factors that affect the business unit and the extent of their impact.

The identification of these factors, and especially their mutual relationship, influences one another and is one of the essential merits of financial analysis.

3. Discovering trends and regularities in the development of economic activity.

4. Analysis of the use of material, labor and financial resources.

5. Evaluation of the implementation of the preliminary plan on the basic quantitative indicators of the established plan calculations and norms.

6. Building the relevant theory of the studied processes - in some cases, theoretical summaries and additions can be made for raising the scientific level and for completing the relevant theories of the studied economic processes and structures.

The financial analysis is not done on its own. Its effectiveness is determined by the amount of the reserves made, the losses prevented and the quality of the managerial decisions taken. 


\section{History of the trade company "Budeshtnost"}

The trade company "Budeshtnost" was founded in 1902 in the city of Chirpan as a metal casting workshop. The then 11,000th town, situated in a richly fertile soil field, among fields companyed with wheat, vegetables, cotton and vineyards is situated in a central location, between the two largest cities in Trakia - Plovdiv and Stara Zagora, had a convenient connection with the surrounding settlements in four directions connected with a railway line from 1889 to Stara Zagora and from 1911 to Plovdiv and Sofia - hence their great influence on its economic, economic, political and cultural development.

The need for machinery to support the work of craftsmen and farmers in this region has called an a workshop "Budeshtnost". The free Bulgaria industry developed relatively quickly, at the time, of course. Registered industrial enterprises reached the impressive figure of 740 and one of them is the metalworking workshop "Budeshtnost", the beginning of which are the brothers Georgi and Hristo Penchevi.

The name of the workshop came naturally. Already at the beginning of 1903 it was already beating as "Budeshtnost": "The future belonged to the technique and my father felt this despite his nephew!" - these are the words about the origin of her name from the son of the owner Vassil Penchev, who worked as a specialist and head of: technological, manufacturing and instrumental departments and completed his entire work experience in this largest enterprise in the region.

In 1991, The metalworking company "Budeshtnost" is registered. Its production specialization is preserved. In the early 1990s, when our country is in an economic crisis and there is stagnation in the markets, the company reduces its staff to 800 people. With a lot of difficulties, he managed to direct his production to the Western markets, but the competition was very high and the quality was lower than the main competitors in this production - Italy and France.

"Budeshtnost" was declared privatized in 1997. through mass privatization. New job cuts have been made. Of the over 2,000 employees of the enterprise, 450 people remain. After 1999, the company continued its efforts to impose its production on foreign markets, with more than $80 \%$ of its industrial output in France, Germany, Italy, Spain, England, Norway, Hungary, Poland, Russia, and also in Turkey, Greece and Egypt. Customers in the domestic market are mainly from the Balkancar companies.

\section{Analysis of some indicators}

\section{Profitability of "Budeshtnost"}

Estimated profitability indicators have negative values. For 2005, they are positive, but practically turn to zero. This means that the realized profit is negligible in relation to the size of the enterprise and the scale of its business. 
It should be noted that despite the balance sheet profit, the financial result of the ordinary activity is negative (BGN -33,000). loss. If the problem becomes even more profound, it is noteworthy that net sales revenue is less than the cost of materials, wages, insurance, and depreciation, and these are costs that no enterprise could have it works. By this I mean that with the revenues from its sales the company cannot cover even the most basic expenses on the economic elements, and without them the production is impossible. Only thanks to the revenues from financing, which is significant (BGN 637,000), the loss from the normal activity is reduced to a more acceptable value. But it has to be taken into account that the revenues from the financing are external to the enterprise and have not been realized as a result of its good work.

Despite the negative result of the activity in 2005, the final financial result is positive. Its positive value is due to the results of the financial activity and the extraordinary operations (total BGN 128,000), which fully compensate for the loss from the ordinary activity. In the end, an accounting profit of BGN 95,000 was received, but significant taxes were charged - BGN 90,000. The minimum value of the realized profit determines the company's too low profitability.

Overall, based on the above table, we can conclude that for the period from 01.01. 2005 to 31.04.2007 "Budeshtnost" has a very unsatisfactory level of profitability. Its financial result is marked by a significant loss. If the enterprise did not receive earnings from the funded (15-25\% of total revenue), it would have incurred significant losses over the period considered. Losses are mainly due to excessive and extraordinary expenses, except for 2005. There is a lasting tendency to increase the efficiency of the ordinary activity, but this is not enough to cover the already mentioned costs.

\section{Efficiency of the enterprise}

In 2005, the cost-effectiveness ratio is slightly higher than a unit (1.02). This is a very low value, which shows that with 1 BGN costs the company realizes BGN 1.02. it is on the boundary between profit and loss. The same shows the revenue efficiency ratio (0.98), according to which the company makes $0.98 \mathrm{BGN}$, the cost of receiving BGN 1 income. These are critical values for these coefficients, reflecting the extremely ineffective work of the company "Budeshtnost".

We can summarize that during the analyzed period, the company has worked inefficiently, as over time the effectiveness is getting worse, reaching dangerous levels. With cost effectiveness 0.8 , an enterprise, if it wishes to survive, should take urgent action.

\section{Liquidity of the enterprise}

For 2005, the company has a fairly good level of total liquidity - the common liquidity ratio has a value of 1.84 . This value is close to the normal for this factor 
(about 2), but it should not drop because this could be considered a negative trend. Primary assets representing 65\% of total short-term assets and short-term receivables $(32 \%)$ play a major role in achieving such a solution of total liquidity. The lowest is the share of cash - 3\%, and they are actually the fastest liquid. The company's fast liquidity ratio has a much lower value than the optimal one - only 0.65 . This means that with available cash, short-term receivables and short-term investments could cover only $65 \%$ of short-term liabilities.

We can summarize that "Budeshtnost" maintains a very low level of liquidity of its assets, with a pronounced trend towards its deterioration. This may lead to delays in payments to creditors, staff, suppliers, postponing major repairs, and other financial difficulties. Extremely low value for immediate and absolute liquidity ratios signals a potential threat of insolvency. It is therefore necessary to take immediate and effective measures to increase the company's liquidity.

\section{Analysis of the financial autonomy of the enterprise}

"Budeshtnost" has a high degree of financial autonomy. In 2005, liabilities of BGN 1 were BGN 5,03 of equity. With its property, the enterprise covers its liabilities several times. This is quite reassuring given the extremely unsatisfactory values of the already analyzed indicators for the financial position of the enterprise.

The large amount of its own capital means that it could cover large losses, and for a long period of time. This, of course, is not desirable, and it only postpones a possible bankruptcy in time, but it is precisely this delay in time that could allow the company to make the necessary changes and reorganizations to make a profit. In addition, the large amount of equity to liabilities means that if the firm goes into insolvency and insolvency proceedings, it will fully satisfy its creditors with its property and will remain property to be distributed among the shareholders.

As can be seen from the solvency ratio, with its own capital, the company can cover almost 6 times more debts than available. The large relative share of equity also has a drawback; it is not possible for the entity to have a strong leverage effect, ie. to increase the profitability of equity by investing and attracting capital. But from a different point of view, the leverage effect can not occur at all, because the company's profit rate is significantly lower than the interest rate on loans.

We can summarize that "Budeshtnost" AD has a very high degree of financial autonomy, but as a result of the loss realized in 2006, and especially due to the significant increase in its liabilities, this financial autonomy is constantly decreasing at a high rate. If this trend persists, at similar rates of leverage, after 1-2 years the entity will face significant financial problems. 


\section{Analysis of the entity's asset structure}

The analyst firm has a high proportion of fixed assets in the total amount of the asset, which may have a negative impact on its adaptability to changes in economic situation. But, on the other hand, this high proportion of fixed assets is justified because the enterprise operates in the sphere of machine building, and for such a production, large investments in fixed assets, and especially in tangible fixed assets, are generally needed. Moreover, the pronounced trend towards a constant decrease in the relative share of fixed assets and at the same time an increase in the share of short-term assets in the total assets is observed, which shows that the company's adaptability gradually improves.

On the whole, we can say that the ratios in the structure of the assets of the balance sheet of Budeshtnost are good and could not be considered as a prerequisite for financial problems. Its adaptability is steadily rising over the period under review, which means that the company will increasingly be able to conduct its business in line with the ever-changing conditions of the economic environment in which it operates.

We have already reviewed and analyzed the profitability, efficiency, liquidity, financial autonomy and asset structure of the company "Budeshtnost". However, these are only individual aspects of the financial position of this entity and their self-analysis is not sufficient to obtain a complete and accurate picture of this financial condition. So we will now make a summary based on all the calculated indicators. Unfortunately, we will not include in our analysis the turnover ratios of short-term tangible assets and receivables and repayment ratios as we do not have information on the average availability of customer receivables and the average availability of liabilities to suppliers.

The combination of low profitability and efficiency, and insufficient liquidity, is too uncomfortable and indicates very serious problems in the company's operation. The enterprise is characterized by great financial autonomy, but it is noticeable that it is rapidly declining due to the rapid increase in the company's short-term liabilities. This would not be a negative trend if the profitability and liquidity of the company were high. Using more leverage could lead to an increase in return on equity due to the "leverage effect". But in the case of the profit rate, it is much lower than the interest rates on loans, and the increase in the borrowed capital along with the low liquidity of the company could even lead to insolvency.

At the same time, the company's adaptability to changes in the economic environment makes a good impression. The relative share of its short-term assets in the total amount of the asset is steadily increasing with a simultaneous decline in the fixed assets, the capital invested in short-term assets is increasing and can be quickly released and redirected. But the good structure of the asset, as we have seen, is not enough to get the business to work well. 


\section{Some recommendations for improvement}

The reasons for the poor financial condition of the enterprise we have analyzed can be divided into internal and external. Internal ones are those that arise from the way it works and on which it can have a direct impact. Outside are the reasons arising from the surrounding environment, to which it must be adapted without being able to change it. We will not consider them separately as they act in a complex way.

Firstly, the general economic situation in Bulgaria must be taken into account. The transition from a centrally planned to a market economy has become extremely unpleasant for the average Bulgarian way. People were totally impoverished, shrinking their consumption to the limit of the living minimum. Many people struggle for their physical survival. As a result of this negligible consumption, especially of groceries, many businesses have gone bankrupt and are very few entrepreneurs who are hiring to make large investments in serious productions. Taking into account that "Budeshtnost" is a machine-building enterprise and its production is almost entirely composed of goods with investment purpose, we can understand how much the domestic market has shrunk for its products. The company has also lost a large part of its traditional foreign markets before 2005. The huge collapse in the amount of output has put the company in a very unimaginable position. His management team had a huge production base, but there were no customers to manufacture. This has led to a staff cut of about 4 times over the past 12-13 years.

In this situation, the company was forced to try to break into the free European market. But it was here that it faced enormous difficulties - insufficient quality of production, relatively high cost, great competition. Additionally, the company is unfamiliar and must be proven to new customers.

The low production quality of Western competitors is determined by the lack of real competition within the company's former markets, the product has been realized even if it is of a lower quality. Therefore, the company did not use technology, technology and personnel to guarantee the quality of the goods produced. It now faces the vital need to bring the quality of its production into line with European standards, and this requires both time and money that the company does not have. The high cost of production is due to the use of obsolete and many energy-intensive machines. The large scale of the enterprise determines large administrative costs, heating costs, maintenance costs, etc., which are subsequently allocated to a small amount of manufactured products, which further increases their cost.

The outcome of the situation is not easy, but I think it is still possible. The management team has to put all its efforts and skills in order to modernize the production in order to make it sufficiently up to date. The task is compounded even more by the fact that high quality must be accompanied, if not with a reduction in price, at least by keeping it at the same level. The necessary means for such a change could come from the sale of part of the enterprise's assets which are not fully utilized and 
which will not be used in the renewed production. This is mainly about machines and equipment that have lagged behind the rapid development of machine-building in Bulgaria, but which do not correspond to the modern requirements for quality and economy. Their sale will not be easy, because those who want to buy such old machines will be less, but it seems to me that at a low enough price they might be interested, for example, some small workshops performing repairs. Such machines would have done them satisfactorily to their needs.

It is true that the machines will be sold at a relatively low price, but they are in any case superfluous and will not be of any real benefit.

Some buildings can also be sold, which are not effectively used due to the small number of staff and limited production activity. With the released funds will be possible activity of the company to reorganize within a small area and using fewer machines, however, will reach optimum load, not just $60 \%$ as to $31.04 .2007 \mathrm{~g}$. Moreover, these machines will be mostly new and economical and will require less maintenance and repair costs.

Investments should also be made to raise staff qualifications and skills to attract specialists to deliver a successful marketing and advertising policy for the company.

The company must also set up a special department to deal with innovation and research. Such a department is missing at the moment, and only he can ensure that the enterprise will keep pace with time and scientific and technical progress.

I see another opportunity to improve the financial condition of "Budeshtnost" AD. It is possible to get it into a prosperous European company with a similar activity. The company will exist as a subsidiary of this company. She will have an interest in the deal because she will have very cheap labor in Bulgaria. After the necessary modernization, the European company will be able to produce in Bulgaria even at lower cost than in Western Europe.

\section{Conclusion}

This paper made a brief characterization of financial analysis as a specific activity aimed at a comprehensive and interrelated study of all aspects of the financial situation of the enterprise. We then applied the analysis to a specific company "Budeshtnost" JSC - Chirpan. We met the past of this company with over 100 years of history. We have seen how dynamically and progressively evolved over time, and what significant success he has achieved in the field of machine building. For the period 1977-1989 it was one of the leading companies in Bulgaria in the field of manufacturing of hydraulic products for industry. The rapid change in the overall economic situation as a result of the transition from a centralized to a market economy puts it in a very difficult situation, along with many other enterprises working in the field. The loss of almost all of the former markets both inside and 
outside the country creates a real threat to its existence, so great efforts are being made to break through the hard-to-reach European markets.

During the period we analyzed in detail, the company is in an unfair financial position. Low profitability is combined with low liquidity. Therefore, immediate steps need to be taken to improve the company's performance.

This will be a tricky process, but with skillful leadership that properly exploits the huge potential of an enterprise, things can greatly improve. Thus, the company "Budeshtnost" JSC Chirpan for several years could become a profitable company, which is attractive for the shareholders and creates many jobs.

\section{REFERENCES}

[1] Accountancy Act, SG, No. 98 from 01.01. 2016.

[2] Снuкov, K., Analysis of Financial Results, S., 1998.

[3] http://btcatalogue.bg/katalog-firmi.aspx?comp=893\&city=\%D0\%A7\%D0\%B8\%D1\%80\%D0\%BF\%D0\%B0\%D0\%BD\&n=\%D0\%91\%D1\%8A\%D0\%B4\%D0\%B5\%D1\%89\%D0\%BD\%D0\%BE$\% \mathrm{D} 1 \% 81 \% \mathrm{D} 1 \% 82$.

[4] http://econ.bg/\%D0\%91\%D1\%8A\%D0\%B4\%D0\%B5\%D1\%89\%D0\%BD\%D0\%BE\%D1\%81 \%D1\%82-\%D0\%90\%D0\%94_l.c_i.221439.html.

[5] http://www.hydraulic-vlv.com/.

[6] Kossev, D., Bilateral Corporate Accountancy, Ed. Softrade, 1999, Sofia.

[7] National accounting standard 1- Presentation of Financial Statements, SG, issue no. 22 of 2002. 
